OPEN ACCESS

International Journal of Management \& Entrepreneurship Research

P-ISSN: 2664-3588, E-ISSN:2664-3596

Volume 2, Issue 5, P.No. 291-303, October, 2020

Fair East Publishers

Journal Homepage: www.fepbl.com/index.php/ijmer

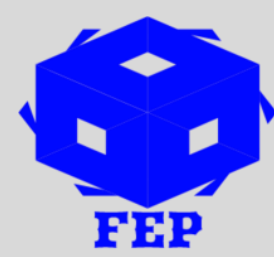

\title{
DOES MARKETING REMAIN AS A DRAWBACK OR RESPONSES TO THE GROWTH OF WOMEN ENTERPRISES OF MANIPUR?
}

\author{
Dr. Yumlembam Linthoi Chanu ${ }^{1}$ \\ ${ }^{1}$ Post-Doctoral Fellow (ICSSR), Department of Commerce, \\ Manipur University, Manipur, India
}

*Corresponding Author: Dr. Yumlembam Linthoi Chanu

Corresponding Author Email: yumlembamlinthoi@gmail.com

Article Received: $30-08-20$

Accepted: 27-09-20

Published: $15-10-20$

Licensing Details: Author retains the right of this article. The article is distributed under the terms of the Creative Commons Attribution-NonCommercial 4.0 License (http://www.creativecommons.org/licences/by-nc/4.0/) which permits non-commercial use, reproduction and distribution of the work without further permission provided the original work is attributed as specified on the Journal open access page.

\section{ABSTRACT}

The purpose of the study is to understand the marketing problems and activities of women enterprises of Manipur; and consequently, to examine their impact on the sales growth. Relatively, a null hypothesis on whether marketing can influence the sales growth of women enterprises was developed and tested to draw inferences and conclusions. The study was felt due to the need for the hour to introspect into the reasons for slow pace of industrial growth and entrepreneurship development in Manipur out of which an assumption is the marketing reasons. Primary data were collected from 200 women entrepreneurs through the face-to-face structured interview based on questions associated with the identified variables of the study, i.e. dependent variable being sales growth and independent variable being marketing. Statistical methods like percentage, median, and chi square test were employed. The primary data were processed through SPSS. The findings of the study reveal that marketing has been a problem for women entrepreneurs of Manipur. However, the chi square test results show that marketing constraints do not have a significant impact on sales growth. The study also reveals that marketing activities performed by women enterprises are branding, packaging, labelling, providing product related services, standardization of products, promotional pricing, use of middlemen as a channel of distribution, sales at counter, personal selling, advertising both conventional and modern, and trade promotion. And that these functions have a significant and positive relationship with sales growth. Hence, the study concludes that though women enterprises face difficulties in marketing the products, does not remain as a drawback and contributes significantly to sales growth. 
Keywords: Women Entrepreneurs, Marketing, Marketing Activities.

\section{INTRODUCTION}

Marketing has been widely recognized as key to an enterprise's strength, weakness, opportunities, and threats. Many authorities have attached crucial roles to marketing by justifying its performance in understanding customers' needs and wants, building a strong brand/product, satisfying customers, attracting and acquiring customers, and in getting a return on investment. Marketing is thus defined as "marketing is the activity, set of institutions, and processes for creating, communicating, delivering, and exchanging offerings that have value for customers, clients, partners, and society at large" (AMA, 2017). It is a societal process by which individual and groups obtain what they need and want through creating, offering, and freely exchanging products and services of value with others (Kotler \& Keller, 2020). From the definitions, it follows that the task of marketing is to offer to the market a product/service which can satisfy customers and which has value to customers. Customer satisfaction is the extent to which product's perceived performance matches a buyer's expectations (Kotler, Armstrong \& Agnihotri, 2019). Value to customers is the sum of tangible and intangible benefits and cost (Gupta, 2019). The tangible values are: functional value i.e. the abilities of a product like usefulness, reliability, durability, performance, resale value, delivery and maintenance; economic value - the price advantage; convenience value the easy availability; sensory /aesthetic value - taste, looks, smell, sound and feel of the product; and service (people) value - promptness and quality of service and good customer relationship.; while the intangible values are: social value - confers social acceptance or social desirability; prestige/status value - product contributes to the user's sense of status/esteem; and belief value - the product reconfirms to user's religious/cultural beliefs (Ramaswamy \& Namakumari, 2009). The implication is that marketing is not only of selling the product through methods and techniques but it is also of knowing the customers and letting the customers know through informing and giving knowledge about the product, ensuring that the product has a value which can meet their various forms of demand, maintaining relations with the customers and the public, and also of promising to their health, safety and welfare. However, a basic question raised for enterprises operating in Manipur especially women owned MSMEs is that of the practicability or inefficacy of such a marketing concept coined around consumer satisfaction and value delivery proposition.

In Manipur, the highest number of women enterprises are found in the micro sector, followed by small and medium respectively. They are mostly engaged in traditional activities like weaving, handloom, handicraft, knitting, embroidery, and food processing industries. They operate with small investment and are labour intensive. The infrastructural facilities available within the enterprise hardly stimulate the use of advance techniques and mechanisms of financing, production and marketing. Their decision making and managerial ability were not high but medium (Ram, Singh, Chaudhary \& Jayarani, 2013). They have low risk bearing ability and are faced with many constraints including mobility, dual responsibility, lack of technical and functional knowledge and skill. Above these, the socio-economic environment and the geophysical feature of Manipur are considerable factors for women enterprises. The social dilemma - must frequent riots, strikes and blockade, under look and unsolved regional 
conflict from long, inefficient transport and communication system, lack of consultancy services and specialized institutions for entrepreneurship development, geographical isolation, ignorant government policy, etc. among others are the atmosphere of entrepreneurship development in Manipur. With the entrepreneurial activities they are involved in, the environment in which they operate, the entrepreneurial traits of women, and the traits of women enterprises, etc. there is always a queried on the marketing orientation of women enterprises. It strikes in and out on marketing being a drawback for women entrepreneurs or a contributing factor to the survival, success, growth and development of women enterprises in Manipur.

\section{Objectives of the Study}

1. To find out the marketing problems of women owned MSMEs of Manipur.

2. To find out the marketing activities of women owned MSMEs of Manipur.

3. To examine the impact of marketing on the growth of women owned MSMEs of Manipur.

\section{LITERATURE REVIEW}

Karam et al (2018) investigated the effect of marketing strategy on organization performance as a private business at Cihan University. The study concludes that marketing strategies which are service strategy, pricing strategy, promotion strategy, place strategy, after sales service strategy, higher education marketing strategies and social media marketing strategies are significantly independent and joint predictors of business performance. The study recommends that SMEs should provide quality services, charge competitive prices, position appropriately, use attractive services for the university, engage in after sales service and provide other distinctive functional benefits.

Gituma (2017) analyzed the effects of marketing mix on sales performance at Unga Group Limited and found that product quality has a positive impact on sales performance; brand awareness influences organizational performance; packaging which is to describe the product, brand image and loyalty influences company's profitability; and pricing strategy increases sales volume. The study also found that store design and use of attractive stimuli such as music has an influence and positively effect consumer purchase and sales volume; while geographical location has a significant influence on profitability, advertising, direct marketing and increases sales volume.

Kasiso (2017) had bring out the effects of marketing strategies on sales performance of small and medium enterprises in Kenya. Consequently, the following can be noted from the study: the adoption of product development strategies resulted to a positive significant effect on sales performance and other business goals such as entering new markets, selling more to existing customers or winning business from competitors; pricing strategies give SMEs the flexibility in setting prices and win new business or maintain prices and increase profit margin however, pricing too low or too high can have unintended consequences to sales; promotional strategies helped to keep customers informed of what the firm offered, informs customers or clients on both the place where to get the product and the price; and place strategies helps to convert foot traffic and online traffic into new customers as well as helps to remove barriers to sales.

Negrut and Mihartescu (2016) has investigated the degree of implementation of marketing function in small and medium enterprises with a view to identify solutions to improve economic performance. Accordingly, the study mentions that over 50\% of the studied enterprises had cooperated with specialized companies or have marketing department of their 
own which provide support to their enterprise in surviving, growing and facing the strong competition of the market. From the $50 \%$ numbers of enterprises, it is again found by the study that more than $50 \%$ belongs to medium sized enterprises because of medium sized enterprises are able to see a development and a steady maintenance on the market in relation to competition, in contrast with small enterprises, who choose marketing based more on promoting on the Internet or other means, without its own marketing department, or collaboration with specialized companies. Similarly, the study of Wirtz, Tuzovic and Kuppetwieser (2014) a strong and influential marketing department contributes positively to firm performance and depends more on its responsibilities and resources, and less on internal contingency factors (i.e., a firm's competitive strategy or institutional attributes). Again, the influence of a marketing department has been stated in the study as more resources driven in large firms, but more responsibility driven in small firms.

Adewale, Adesola and Oyewale (2013) talks about the impact of marketing strategy on business performance. According to the study, the order correlation analysis and multiple regression analysis shows that the relationship between business performance and the marketing strategies are positive and significant and that they are independent predictors of business performance. The study states that high quality product produced by business organizations, effective channel of distribution employed by business organizations, affordable price charged, attractive packaging used for the product and effective after sales service helps in the higher business performance in terms of profitability, market share, return on investment and expansion. However, the study shows that there is negative but significant relationship between business performance and promotion the reason of which is mostly attributed to the consumer perception of heavily promoted products to be of poor quality products with passed expiry dates and from clearance stocks. The understanding of innovative marketing practices applicable to SMEs by Trivedi (2013) can be added in the literature. The study has laid down the following innovative marketing techniques for SMEs: WWW as a promotional tool, customer relationship management (CRM), digital advertising, mobile advertising, reaching out best qualified prospects, improving feedback mechanism, following up leads and convert it in sales, generating new sparks (ideas), and cluster approach.

\section{METHODOLOGY}

The study is empirical research in nature conducted to provide an understanding on whether marketing remain as a drawback for women enterprises of Manipur or does it add to their growth objectives. This purpose of the study is planned to be fulfilled through (i) first, identifying the kinds of marketing problems face by women enterprises and their bearing on sales growth; (ii) second, identifying the marketing activities of women enterprises and their impact on sales growth, (iii) lastly, by comparing the degree of influence/impact that each kind of marketing problems and activities has on sales growth of women enterprises. Here, the study has defined women enterprises as "those enterprises set up and operated by women entrepreneurs".

For the study both primary data and secondary data were collected. Secondary data from Nucleus Cell, Directorate of Commerce and Industries, Government of Manipur were used to determine the population size of the study. 20000 units registered as MSMEs (Micro, Small and Medium Enterprises) under the sole proprietorship of women entrepreneurs engaged in the manufacturing of products formed the population size of the study. From the given $\mathrm{N}$ size, 
a sample of 200 units were drawn. Women entrepreneurs identified as the sample unit of the study has been defined as "women entrepreneurs are women who own and controlled an enterprise with a minimum financial interest of 51 percent of the capital". Primary data of the study were the views and opinions of women entrepreneurs obtained through face-to-face interview based on the list of structured questions embodied in the schedule. The questions included were of nominal and ordinal scale and closed ended. Chi-square test and correlation analysis were used to identify the level of significance between various marketing and sales growth. Besides, the descriptive statistical methods used were frequency, percentage and median.

\section{FINDINGS AND ANALYSIS OF PRIMARY DATA}

Who are the Women Entrepreneurs of Manipur? Women entrepreneurs of Manipur are the ones who operate micro, small and medium enterprises after acquiring skill and knowledge of operating and/or managing an enterprise through formal and informal training which also include knowledge and skill passed on from ancestors. From Chanu and Chanu (2014) it is known that women enterprises are more concentrated on valley areas and the majority of them prefer to be engaged in manufacturing of products rather than providing services. According to them, women entrepreneurs are mostly engaged in handloom, weaving and tailoring in the area of manufacturing but are also taking up all kinds of entrepreneurial venture such as cattle rearing, furniture and fittings, iron and steel, jewellery, press and printing, clinics, pharmaceuticals, computer works and studios, and videography, etc.

What Motivates Women to Become an Entrepreneurs? Women of Manipur became entrepreneurs not only for the sole purpose of earning revenue or searching for livelihood, but some women who have a desire to become an entrepreneur. Hence, both pull and push factors motivates women to become entrepreneurs. However, the majority of women are driven by push factors such as earning of income and livelihood (21.5\%), unemployment (17.5\%), supplementing family income (11.0\%), continuation of family business $(6.0 \%)$, no other means of livelihood $(4.0 \%)$, and multiple such reasons $(6.5 \%)$ forces them to become entrepreneurs. While, pull factors that drive women to become entrepreneurs are desire and willingness to become an entrepreneur $(8.0 \%)$, desire to create employment $(0.5 \%)$ and production $(5.5 \%)$, to be independent and self employed $(14.5 \%)$, and skilled in the field $(5.0 \%)$. The push factor ranges around 66.5 percent of the total sample while pull factors which are the luring or attracting factors range around 33.5 percent of the total sample size. This is revealed in Table 1 of the study.

Table 1

Reasons for Becoming Entrepreneur

\begin{tabular}{lcc}
\hline \multicolumn{1}{c}{ Parameters } & Frequency & Percentage \\
\hline Desire and willingness & 16 & 8.0 \\
To earn income and livelihood & 43 & 21.5 \\
To create employment & 1 & 0.5 \\
To create production & 11 & 5.5 \\
Unemployment & 35 & 17.5 \\
Self employment & 29 & 14.5 \\
To supplement family income & 22 & 11.0 \\
Continuation of family business & 12 & 6.0 \\
No other means of livelihood & 8 & 4.0 \\
Skilled in the field & 10 & 5.0 \\
\hline
\end{tabular}




\begin{tabular}{lcl}
\hline Multiple reasons & 14 & 6.5 \\
Total & $\mathbf{2 0 0}$ & $\mathbf{1 0 0 . 0}$ \\
\hline
\end{tabular}

What are the marketing problems of women entrepreneurs of Manipur? Table 3 reveals that the marketing problems of women entrepreneurs of Manipur are manifold, most of which are intrinsic to the organization while only a few are extrinsic to the organization. The marketing problems encountered by women entrepreneurs of Manipur that are intrinsic to their enterprise are: the problem of acquiring raw materials for the production process $(11.5 \%)$; limited range of products $(9.0 \%)$; limited installed capacity $(4.0 \%)$; the problem of storage $(3.5 \%)$; the problem of acquiring labour/worker and frequent employee turnover (2.0\%); low frequency of purchase by customers (5.5\%); unable to meet customers' demand (26.5\%); inability to explore new market and attract customers therefrom (19.5\%); inability to install new techniques of production (3.5\%); inability to bear the cost involve in expansion and development $(3.0 \%)$ and the inability to bear the cost involved in the promotion and/or advertising their products. The only marketing problem of women entrepreneurs which is extrinsic to their enterprise is the competition that they face from other large and heavy industries, male counterparts as well as another micro, small and medium enterprises operating in the region.

Again, the problem of acquiring raw materials has been classified as intrinsic to the enterprise it is found that this problem is often not related to the enterprise or entrepreneur such as the financial or other problems faced by women entrepreneurs while acquiring it, but is mostly related to the problem of suppliers not being available in the region or fluctuation in the prices of the raw materials, etc. and therefore it is more suitable to classify raw material problems as problem specific to the region.

Table 2

\begin{tabular}{clcc} 
Marketing Problems of Women Entrepreneurs of Manipur & \multicolumn{1}{c}{ Parameters } & Frequency & Percentage \\
\hline S. No. & & 23 & 11.5 \\
\hline 1 & Problem of acquiring raw materials for production process & 18 & 9.0 \\
2 & Limited range of products & 8 & 4.0 \\
3 & Limited installed capacity & 7 & 3.5 \\
4 & Problem of storage & 4 & 2.0 \\
5 & Problem of acquiring labour/worker and frequent employee turnover & 11 & 5.5 \\
6 & Low frequency of purchase by customers & 53 & 26.5 \\
7 & Unable to meet customers' demand & 39 & 19.5 \\
8 & Inability to explore new market and attract customers therefrom & 7 & 3.5 \\
9 & Inability to install new techniques of production & 10 & 5.0 \\
10 & Competition from other units & 6 & 3.0 \\
11 & Inability to bear the cost involve in expansion and development & 14 & 7.0 \\
12 & Inability to bear the cost involved in promotion and/or advertising their & Total & 200 \\
& products & Source: Field Survey & 100.0 \\
\hline
\end{tabular}

Source: Field Survey

What are the Marketing Functions of Women Owned MSMEs of Manipur? The marketing functions of women owned MSMEs of Manipur are shown in Table 4 of the study as follows: that majority of the women entrepreneurs are not involved in marketing functions of branding, labelling, packaging, advertising (both conventional and modern) and other kinds 
of trade promotion activities. However, majority of them are involved in such marketing activities like: providing after sales services such as repair, replacement and refund of defective goods, etc. with 82.5 percent of the sample coverage; maintaining standards for the products in terms of the size, design, quality, quantity, etc. covering around 77.5 percent of the sample; using different methods of promotional pricing such as price cutting, providing cash as well as trade discounts to consumers and middlemen/agents etc., giving premium and concessions on bulk purchase and other purchases, etc. covering about 67 percent of the study sample; engaging middlemen for sales activity is another marketing practice of 58.5 percent of the women entrepreneurs of Manipur; sales at counter is the marketing activity of almost all the sample entrepreneurs (100\% of sample units); another major marketing activity performed by 78.5 percent of women entrepreneurs of Manipur is the practice of different methods of personal selling like demonstration of the products, giving attention to customers need and demand, and follow up of sales and also the practice of adopting different methods of trade promotion like participating and/or organizing trade fairs and exhibitions, etc. is another marketing activity performed by 60 percent of the study sample.

Table 3

Marketing Functions of Women Entrepreneurs of Manipur

\begin{tabular}{|c|c|c|c|c|c|c|}
\hline \multirow[t]{3}{*}{ S. No. } & \multirow[t]{3}{*}{ Parameters } & \multicolumn{4}{|c|}{ Sample Units } & \multirow{3}{*}{$\begin{array}{l}\text { Total } \\
\text { Units }\end{array}$} \\
\hline & & \multicolumn{2}{|c|}{ Yes } & \multicolumn{2}{|c|}{ No } & \\
\hline & & Frequency & Percentage & Frequency & Percentage & \\
\hline 1 & Branding of the products & 32 & 16.0 & 168 & 84.0 & 200 \\
\hline 2 & Packaging of the products & 73 & 36.5 & 127 & 63.5 & 200 \\
\hline 3 & Labelling of the products & 56 & 28.0 & 144 & 72.0 & 200 \\
\hline 4 & $\begin{array}{l}\text { Providing services related to the } \\
\text { products }\end{array}$ & 165 & 82.5 & 35 & 17.5 & 200 \\
\hline 5 & $\begin{array}{l}\text { Maintaining standards for the } \\
\text { products }\end{array}$ & 155 & 77.5 & 45 & 22.5 & 200 \\
\hline 6 & $\begin{array}{l}\text { Different methods of promotional } \\
\text { pricing }\end{array}$ & 134 & 67.0 & 66 & 33.0 & 200 \\
\hline 7 & Use of middlemen for sales & 117 & 58.5 & 83 & 41.5 & 200 \\
\hline 8 & Sales at counter & 200 & 100.0 & 0 & 0.0 & 200 \\
\hline 9 & $\begin{array}{l}\text { Different methods of personal } \\
\text { selling }\end{array}$ & 157 & 78.5 & 43 & 21.5 & 200 \\
\hline 10 & $\begin{array}{l}\text { Conventional methods of } \\
\text { advertising }\end{array}$ & 99 & 49.5 & 101 & 50.5 & 200 \\
\hline 11 & Modern methods of advertising & 47 & 23.5 & 153 & 76.5 & 200 \\
\hline 12 & $\begin{array}{l}\text { Different methods of trade } \\
\text { promotion }\end{array}$ & 120 & 60.0 & 80 & 40.0 & 200 \\
\hline
\end{tabular}

Source: Field Survey

\section{What is the Impact of Marketing on Sales Growth?}

To know about the relationship between marketing and sales growth, an effort is made to find out whether the various kinds of marketing problems faced by women enterprises and the marketing activities these enterprises performed have a bearing on sales growth. For this women entrepreneurs are asked to mark their opinion on nominal value - Yes or No, as well as on ordinal value - very high degree (1), high degree (2), moderate degree (3), low degree (4), very low degree (5). The responses are reflected in tables 3 and 4 below. Tables 3 and 4 has been interpreted with the help of percentage and median value.

Table 3 reveals that the listed marketing problems like a limited range of products, inability to bear the cost involved in product expansion and development and inability to install new techniques of production have little or no bearing on sales growth, while other listed problems 
have influence on sales growth but to marginal sections. The majority of women enterprises are found to be not affected by marketing problems on sales growth except for the problem of competition from other units, in which case it is found that 60 percent of women enterprises are affected in terms of sales growth. It is also found that the listed marketing problems are seen to influence sales growth at a moderate and low degree.

Table 4

Impact of Marketing Problems on Sales Growth

\begin{tabular}{|c|c|c|c|c|c|c|c|c|c|c|c|}
\hline \multirow[t]{2}{*}{ Parameters } & \multicolumn{4}{|c|}{$\begin{array}{l}\text { Impact on Sales Growth } \\
\text { Impact }\end{array}$} & \multicolumn{7}{|c|}{ Degree of Impact } \\
\hline & \multicolumn{2}{|c|}{ Response } & \multirow{2}{*}{$\begin{array}{l}\text { Percent } \\
21.7 \% \\
78.3 \%\end{array}$} & \multirow{2}{*}{$\begin{array}{l}\text { Total } \\
23\end{array}$} & \multirow{2}{*}{\multicolumn{2}{|c|}{$\begin{array}{ll}\mathbf{1} & \mathbf{2} \\
0 & 0\end{array}$}} & \multirow{2}{*}{$\begin{array}{l}3 \\
1\end{array}$} & \multirow{2}{*}{$\begin{array}{l}4 \\
4\end{array}$} & \multirow{2}{*}{5} & \multirow{2}{*}{$\begin{array}{l}\text { Total } \\
7\end{array}$} & \multirow{2}{*}{$\begin{array}{l}\text { Median } \\
\text { Value } \\
4\end{array}$} \\
\hline Problem of raw materials & $\begin{array}{l}\text { Yes } \\
\text { No }\end{array}$ & $\begin{array}{l}7 \\
16\end{array}$ & & & & & & & & & \\
\hline Limited range of products & $\begin{array}{l}\text { Yes } \\
\text { No }\end{array}$ & $\begin{array}{l}3 \\
15\end{array}$ & $\begin{array}{l}16.7 \% \\
83.3 \%\end{array}$ & 18 & 0 & 0 & 0 & 2 & 1 & 3 & 4 \\
\hline Limited installed capacity & $\begin{array}{l}\text { Yes } \\
\text { No }\end{array}$ & $\begin{array}{l}1 \\
7\end{array}$ & $\begin{array}{l}12.5 \% \\
87.5 \%\end{array}$ & 8 & 0 & 0 & 0 & 1 & 0 & 1 & 4 \\
\hline Problem of storage & $\begin{array}{l}\text { Yes } \\
\text { No }\end{array}$ & $\begin{array}{l}3 \\
4\end{array}$ & $\begin{array}{l}42.9 \% \\
57.1 \%\end{array}$ & 7 & 0 & 0 & 2 & 1 & 0 & 3 & 3 \\
\hline $\begin{array}{l}\text { Labour/worker or employee } \\
\text { related problem }\end{array}$ & $\begin{array}{l}\text { Yes } \\
\text { No }\end{array}$ & $\begin{array}{l}2 \\
2\end{array}$ & $\begin{array}{l}50 \% \\
50 \%\end{array}$ & 4 & 0 & 0 & 0 & 2 & 0 & 2 & 4 \\
\hline $\begin{array}{l}\text { Low frequency of purchase by } \\
\text { customers }\end{array}$ & $\begin{array}{l}\text { Yes } \\
\text { No }\end{array}$ & $\begin{array}{l}7 \\
4\end{array}$ & $\begin{array}{l}63.6 \% \\
36.4 \%\end{array}$ & 11 & 0 & 3 & 1 & 2 & 1 & 7 & 3 \\
\hline $\begin{array}{l}\text { Unable to meet customers' } \\
\text { demand }\end{array}$ & $\begin{array}{l}\text { Yes } \\
\text { No }\end{array}$ & $\begin{array}{l}13 \\
40\end{array}$ & $\begin{array}{l}24.5 \% \\
75.5 \%\end{array}$ & 53 & 1 & 5 & 2 & 4 & 1 & 13 & 3 \\
\hline $\begin{array}{l}\text { Inability to explore new market } \\
\text { and attract customers therefrom }\end{array}$ & $\begin{array}{l}\text { Yes } \\
\text { No }\end{array}$ & $\begin{array}{l}10 \\
29\end{array}$ & $\begin{array}{l}25.6 \% \\
74.4 \%\end{array}$ & 39 & 0 & 1 & 4 & 3 & 2 & 10 & 3.5 \\
\hline $\begin{array}{l}\text { Inability to install new } \\
\text { techniques of production }\end{array}$ & $\begin{array}{l}\text { Yes } \\
\text { No }\end{array}$ & $\begin{array}{l}0 \\
7\end{array}$ & $\begin{array}{l}0 \\
100 \%\end{array}$ & 7 & 0 & 0 & 0 & 0 & 0 & 0 & ---- \\
\hline Competition from other units & $\begin{array}{l}\text { Yes } \\
\text { No }\end{array}$ & $\begin{array}{l}6 \\
4\end{array}$ & $\begin{array}{l}60.0 \% \\
40.0 \%\end{array}$ & 10 & 1 & 1 & 2 & 1 & 1 & 6 & 3 \\
\hline $\begin{array}{l}\text { Inability to bear the cost involve } \\
\text { in product expansion and } \\
\text { development }\end{array}$ & $\begin{array}{l}\text { Yes } \\
\text { No }\end{array}$ & $\begin{array}{l}1 \\
5\end{array}$ & $\begin{array}{l}16.7 \% \\
83.3 \%\end{array}$ & 6 & 0 & 0 & 0 & 1 & 0 & 1 & 4 \\
\hline $\begin{array}{l}\text { Inability to bear the cost } \\
\text { involved in promotion and/or } \\
\text { advertising their products }\end{array}$ & $\begin{array}{l}\text { Yes } \\
\text { No }\end{array}$ & $\begin{array}{l}5 \\
9\end{array}$ & $\begin{array}{l}35.7 \% \\
64.3 \%\end{array}$ & 14 & 0 & 1 & 2 & 1 & 1 & 5 & 3 \\
\hline
\end{tabular}

Source: Field Survey and SPSS generated

Table 5 reveals that women entrepreneurs of Manipur are involved in one or more of the listed marketing activities and sales at the counter are the marketing practice of every women entrepreneur of Manipur. It is also known that all the listed marketing activities performed by 
women owned MSMEs of Manipur have an influence on sales growth. The majority of women enterprises are involved in the listed marketing activities. Among all, the only marketing activity that is found to have a very high degree of influence on sales growth is sales at the counter. Another significant degree of influence found is the high degree of influence on sales growth exercise by branding, standardization and different methods of personal selling. While other listed marketing activities are found to contribute to sales growth at a moderate and low degree. However, none of the marketing activities listed are found to influence sales growth at a very low degree. Above, the findings of the study reveal that packaging (91.8 percent), providing product related services (95.8 percent), maintaining standards ( 90.9 percent), and sales at the counter ( 94.0 percent) are largely conducted by women owned MSMEs of Manipur.

Table 5

Impact of Marketing on Sales Growth

\begin{tabular}{|c|c|c|c|c|c|c|c|c|c|c|}
\hline \multirow[t]{3}{*}{ Parameters } & \multicolumn{8}{|c|}{ Impact on Sales growth } & \multirow{3}{*}{$\begin{array}{l}\text { Total } \\
\text { Units }\end{array}$} & \multirow{3}{*}{$\begin{array}{l}\text { Median } \\
\text { Value }\end{array}$} \\
\hline & \multicolumn{3}{|c|}{ Response } & \multicolumn{5}{|c|}{ Degree of Impact (scale value) } & & \\
\hline & Yes & No & Total & 1 & 2 & 3 & 4 & 5 & & \\
\hline \multirow[t]{2}{*}{ Branding of the products } & 28 & 4 & 32 & & & & & & & \\
\hline & $87.5 \%$ & $12.5 \%$ & & 5 & 14 & 4 & 3 & 2 & 28 & 2 \\
\hline \multirow{2}{*}{$\begin{array}{l}\text { Packaging } \\
\text { products }\end{array}$} & 67 & 6 & 73 & & & & & & & \\
\hline & $91.8 \%$ & $8.3 \%$ & & 2 & 6 & 21 & 24 & 14 & 67 & 4 \\
\hline \multirow[t]{2}{*}{ Labelling of the products } & 47 & 9 & 56 & & & & & & & \\
\hline & $83.9 \%$ & $16.1 \%$ & & 3 & 5 & 28 & 8 & 3 & 47 & 3 \\
\hline \multirow{2}{*}{$\begin{array}{l}\text { Providing services } \\
\text { related to the products }\end{array}$} & 158 & 7 & 165 & & & & & & & \\
\hline & $95.8 \%$ & $4.2 \%$ & & 19 & 39 & 54 & 32 & 14 & 158 & 3 \\
\hline \multirow{2}{*}{$\begin{array}{l}\text { Maintaining standards } \\
\text { for the products }\end{array}$} & 141 & 14 & 155 & & & & & & & \\
\hline & $90.9 \%$ & $9.1 \%$ & & 29 & 90 & 9 & 11 & 2 & 141 & 2 \\
\hline \multirow{2}{*}{$\begin{array}{l}\text { Different methods of } \\
\text { promotional pricing }\end{array}$} & 117 & 17 & 134 & & & & & & & \\
\hline & $87.3 \%$ & $12.7 \%$ & & 11 & 28 & 72 & 2 & 4 & 117 & 3 \\
\hline \multirow{2}{*}{$\begin{array}{l}\text { Use of middlemen for } \\
\text { sales distribution }\end{array}$} & 98 & 19 & 117 & & & & & & & \\
\hline & $83.8 \%$ & $16.2 \%$ & & 4 & 23 & 11 & 48 & 12 & 98 & 4 \\
\hline \multirow[t]{2}{*}{ Sales at counter } & 188 & 12 & 200 & & & & & & & \\
\hline & $94.0 \%$ & $6.0 \%$ & & 93 & 60 & 19 & 13 & 3 & 188 & 2 \\
\hline \multirow{2}{*}{$\begin{array}{l}\text { Different methods of } \\
\text { personal selling }\end{array}$} & 134 & 23 & 157 & & & & & & & \\
\hline & $85.4 \%$ & $14.6 \%$ & & 34 & 61 & 23 & 11 & 5 & 134 & 2 \\
\hline \multirow{2}{*}{$\begin{array}{l}\text { Conventional methods of } \\
\text { advertising }\end{array}$} & 82 & 17 & 99 & & & & & & & \\
\hline & $82.8 \%$ & $17.2 \%$ & & 5 & 20 & 34 & 16 & 7 & 82 & 3 \\
\hline \multirow{2}{*}{$\begin{array}{l}\text { Modern methods of } \\
\text { advertising }\end{array}$} & & 9 & 47 & & & & & & & \\
\hline & $80.9 \%$ & $19.1 \%$ & & 0 & 8 & 25 & 2 & 3 & 38 & 3 \\
\hline \multirow{2}{*}{$\begin{array}{l}\text { Different methods of } \\
\text { trade promotion }\end{array}$} & 102 & 18 & 120 & & & & & & & \\
\hline & $85.0 \%$ & $15.0 \%$ & & 8 & 4 & 31 & 50 & 9 & 102 & 4 \\
\hline
\end{tabular}




\section{Hypotheses of the Study}

Statistically testable hypotheses that have been formulated and tested in order to draw inferences on the relationship between variables identified are as follows:

1) $\mathrm{H}_{\mathrm{O}}$ : Marketing problem does not have an impact on the sales growth of women owned MSMEs of Manipur

$\mathrm{H}_{\mathrm{A}}$ : $\quad$ Marketing problem of women entrepreneurs have an impact on the sales growth of women owned MSMEs of Manipur

2) $\mathrm{H}_{\mathrm{O}}$ : Marketing activity does not have an impact on the sales growth of women owned MSMEs of Manipur

$\mathrm{H}_{\mathrm{A}}$ : Marketing activities have an impact on the sales growth of women owned MSMEs of Manipur

Table 6

Chi square Test between Marketing Variables and Sales Growth

\begin{tabular}{llllr}
\hline & Parameters & Value & df & $\begin{array}{c}\text { Asymp. Sig. } \\
\text { (2-sided) }\end{array}$ \\
\hline \multirow{4}{*}{ Marketing problems } & Pearson Chi-Square & $19.334^{\mathrm{a}}$ & 11 & .055 \\
& Likelihood Ratio & 20.248 & 11 & .042 \\
& Linear-by-Linear Association & .325 & 1 & .568 \\
& N of Valid Cases & 200 & & \\
& Pearson Chi-Square & $29.067^{\mathrm{a}}$ & 11 & .002 \\
& Likelihood Ratio & 31.246 & 11 & .001 \\
Marketing activities & Linear-by-Linear Association & 7.347 & 1 & .007 \\
& N of Valid Cases & 1355 & & \\
\hline & Source: Field Survey and SPSS generated & &
\end{tabular}

Table 7

Summary of Hypotheses Test Results

\begin{tabular}{lcc}
\hline \multicolumn{1}{c}{ Hypotheses testing } & $\begin{array}{c}\text { Impact of marketing problems on } \\
\text { sales growth }\end{array}$ & $\begin{array}{c}\text { Impact of marketing activities on sales } \\
\text { growth }\end{array}$ \\
\hline Value & $.055>.05$ & $.002<.05$ \\
$\begin{array}{l}\text { Asymp. Sig. (2-sided) } \\
\text { Result }\end{array}$ & Accept & Reject \\
\hline \multicolumn{2}{c}{}
\end{tabular}

The hypotheses test results show that the null hypothesis number (1) has been accepted and therefore the alternate hypothesis is rejected. While for hypothesis number (2), the null hypothesis has been rejected and the alternate hypothesis has been accepted. This shows that there does not exist a statistically significant relationship between marketing problems and sales growth however, there exists a statistically significant relationship between marketing activities and sales growth. It can be stated that though women enterprises face different types of marketing related problems, these problems do not have an impact on sales growth. But the marketing activities contribute to the sales growth of women enterprises. Hence, it has been concluded that branding, labelling, packaging, providing product related services, standardization, engaging middlemen, sales at the counter, personal selling, both conventional and modern advertising methods, and trade promotion activities of marketing are significantly related to the sales growth of women owned micro, small and medium enterprises of Manipur. 
Table 8

Degree of Marketing Impact on Sales Growth

\begin{tabular}{|c|c|c|c|c|c|c|}
\hline \multirow[t]{2}{*}{ Parameters } & \multicolumn{5}{|c|}{ Degree of impact } & \multirow{2}{*}{$\begin{array}{l}\text { Median } \\
- \text { Value }\end{array}$} \\
\hline & $\begin{array}{l}\text { Very high } \\
\text { degree (1) }\end{array}$ & $\begin{array}{l}\text { High degree } \\
\text { (2) }\end{array}$ & $\begin{array}{l}\text { Moderate } \\
\text { degree (3) }\end{array}$ & $\begin{array}{l}\text { Low degree } \\
(4)\end{array}$ & $\begin{array}{l}\text { Very low } \\
\text { degree (5) }\end{array}$ & \\
\hline Impact of marketing problems & 2 & 11 & 14 & 22 & 9 & 4 \\
\hline Impact of marketing activities & 213 & 358 & 331 & 220 & 78 & 3 \\
\hline
\end{tabular}

Source: Field Survey and SPSS generated

Subsequently, the calculated mean value on the degree of impact shows that marketing problems face by sample women enterprises of Manipur have a low degree of impact on sales growth while marketing activities performed by sample women enterprises of Manipur has a moderate degree of impact on sales growth. Since the degree of impact exercised by marketing activities is greater than the degree of impact exercised by marketing problems. Hence, the study concludes that marketing may pose difficulties to women enterprises but cannot be considered as a drawback in achieving growth goals especially sales growth rather can be viewed as a contributor to growth goal.

\section{FINDINGS AND SUGGESTIONS}

It is found from the study that despite of problems and difficulties faced in varied ways and forms, women entrepreneurs take the zeal to set up an enterprise, operate it, and sets a goal to expand their business operation, achieve success, and grow. Most of the women owned MSMEs of Manipur became an entrepreneur due to push factor, it is very few of them which has been motivated by pull factors such as desire and willingness, to be independent and self employed, and contribute to state's production and employment. Marketing problems are varied and so also the marketing activities performed however if gauge upon marketing has a far more significant role to play on sales growth than to remain as a hurdle. The study reveals that the degree of positive influence marketing has on sales growth is moderate which is higher than the degree of negative influence marketing has on sales growth and that is low. This means marketing contributes to sales growth if women entrepreneurs participate and take initiative in the existing forms of marketing tactics and methods. These marketing activities that have a positive and significant relation with sales growth are branding, labelling, packaging, providing product related services, standardization, engaging middlemen, sales at the counter, personal selling, both conventional and modern advertising methods, and trade promotion. However, the majority of the study units are not involved in marketing functions or activities. This can be an attributable reason for a narrower view prevailing among women entrepreneurs of Manipur, on marketing as advertising and other promotional activities, that marketing needs huge expenditure, and is more relevant and successful if performed by successful enterprises and large-scale industries.

Therefore, the study suggests women entrepreneurs to involved in marketing activities as marketing is of varied forms and successful marketing tactics does not always require huge investment or specialization. The emergence of social media marketing and online marketing itself is a paradigm shift from large investment prerequisites to affordable investment.

\section{CONCLUSIONS}

Marketing is recognized to play the biggest role in integrating all functions and activities of an organization for effectively achieving its success and growth goals. It is the means to acquire customers, capture market shares and consequently bring about ease of production and sales 
process, and resulting in anticipated return on investment. But to most enterprises who operate under the condition of limited ability and capacity like women enterprises of Manipur, the scope of marketing might be narrower and have a diminishing role to play as compared to MNCs and large scale companies. The study indeed found that women entrepreneurs of Manipur face different kinds of marketing problems some of which may be attached to production process related problems, some to distribution and logistics, as well as to promotion and advertising, etc. However, to conclude that marketing is a drawback for women enterprises of Manipur would be incorrect. For marketing to settle down as a drawback requires the degree of effect marketing problems has on sales growth to exceed the degree of the influence marketing function has on sales growth (concept specific to the present study). The findings of the study reveal that the degree of influence marketing activities has on sales growth exceeds the degree of influence exercise by marketing problems. Therefore, the study concludes that marketing problems affect sales growth but do not remain as a drawback and that marketing contribute to sales growth in one form or the other. Hence, the study supports the shared perception of marketing being vital to the survival, success, growth and development of an enterprise.

\section{References}

Adewale, G., Adesola, M. A., \& Oyewale, I. O. (2013, July-August). Impact of Marketing Strategy on Business Performance: A Study of Selected Small and Medium Enterprises (SMEs) in Oluyole Local Government, Ibadan, Nigeria. IOSR Journal of Business and Management (IOSR-JBM), 11(4), 59-66. Retrieve from https://www.iosrjournals.org/iosr-jbm/papers/Vol11-issue4/I01145966.pdf

Chanu, Y. L. \& Chanu, A. I. (2014, June). Women Entrepreneurs of Manipur After MSME Act, 2006: An Analysis. Journal of Entrepreneurship and Management, 3(2), 37-43.

Gupta, C. B. (2019). Principles of Marketing (4th ed.). Daryaganj, New Delhi: Sultan Chand \& Sons

Gituma, M. M. (2017). Effects of Marketing Mix on Sales Performance: A Case of Unga Group Limited (Doctoral thesis), Available from http://erepo.usiu.ac.ke/bitstream/handle/11732/3664/MICHAEL\%20MWENDA\%20G ITUMA\%20MBA\%202017.pdf?sequence $=1 \&$ isAllowed $=y$

Karam, A. A., Hamo, R. H., Rashid, H. M., Jarjes, D. A., Mohammed, C. S., \& Obaid, S. H. (2018). The Effect of Marketing Strategy Implementation on Organization Performance as a Private Business: Case of Cihan University Duhok Camps KRGIraq. International Journal of Business Management and Economics Research (IJBMER), 9(3), 1281-1295. Retrieve from http://www.ijbmer.com/docs/volumes/vol9issue3/ijbmer2018090304.pdf

Kasiso, M.C. (2017). The Effects of Marketing Strategies on Sales Performance of Small and Medium Enterprises in Kenya (Master dissertation). Available from http://erepository.uonbi.ac.ke/bitstream/handle/11295/102665/Muola

Kotler, P., Armstrong, G., \& Agnihotri, P. (2019). Principles of Marketing (17 ${ }^{\text {th }}$ Ed.). Uttar Pradesh: Pearson India Education Services Pvt. Ltd.

Kotler, P., \& Keller, K. L. (2020). Marketing Management (15 ${ }^{\text {th }}$ Ed.). Uttar Pradesh: Pearson India Education Services Pvt. Ltd. 
Negrut, M. L., \& Mihartescu, A. A. (2016). Market Study on Performance of the Marketing Function in Small and Medium Enterprises in Romania. Procedia - Social and Behavioral Sciences, 119-125. Retrieve from https://www.sciencedirect.com

Ram, D., Singh, M. K., Chaudhary, K. P., \& Jayarani, L. (2016). Entrepreneurship behaviour of women entrepreneurs in Imphal of Manipur. Indian Research Journal of Extension Education, 13(2), 31-35.

Ramaswamy, V. S., \& Namakumari, S. (2009). Marketing Management (4th ed.). Daryaganj, New Delhi: Macmillan Publishers India Ltd

Trivedi, J. Y. (2013). A Study on Marketing Strategies of Small and Medium Sized Enterprises. Research Journal of Management Sciences, 2 (8), 20-22. Retrieve from https://www.researchgate.net/publication/293452646_

Wirtz, J., Tuzovic, S., \& Kuppetwieser , V. (2014). The Role of Marketing in Todays' Enterprises. Journal of Service Management, 25 (2), 171-194. Retrieve from https://www.researchgate.net/publication/239261685 